\title{
Growth profile of Carboxydothermus hydrogenoformans on pyruvate
}

\author{
Mathieu Haddad ${ }^{1,2}$, Ruxandra Cimpoia ${ }^{2}$, Ya Zhao ${ }^{2,3}$ and Serge R Guiot ${ }^{1,2^{*}}$
}

\begin{abstract}
Carboxydothermus hydrogenoformans is a thermophilic anaerobic strain most widely known for its ability to produce hydrogen $\left(\mathrm{H}_{2}\right)$ when grown on carbon monoxide (CO). Although relatively well studied, growth characterization on pyruvate has never been assessed. The present work fully characterizes growth of the bacterium on pyruvate as a sole carbon source. C. hydrogenoformans demonstrated a growth rate of $0.03 \mathrm{~h}^{-1}$, with pyruvate consumption ranging between 0.21 and $0.48 \mathrm{~mol} \cdot \mathrm{g}^{-1}$ volatile suspended solid $\cdot \mathrm{d}^{-1}$. A lag phase was also observed when switching from pyruvate to $\mathrm{CO}$. When grown simultaneously on pyruvate and $\mathrm{CO}$, pyruvate consumption was initiated upon $\mathrm{CO}$ depletion. This was attributed to pyruvate oxidation inhibition by $\mathrm{CO}$, and not to a diauxic phenomenom. The strain also showed homoacetogenic activity.
\end{abstract}

Keywords: Carbon monoxide; Water-gas shift reaction; C. hydrogenoformans; Pyruvate

\section{Introduction}

Gasification of biomass and waste is a way to produce non-fossil hydrogen and involves a high temperature $\left(750-1500^{\circ} \mathrm{C}\right)$ conversion of any carbonaceous material into a synthesis gas (syngas) mainly composed of carbon monoxide $(\mathrm{CO})$, carbon dioxide $\left(\mathrm{CO}_{2}\right)$ and hydrogen $\left(\mathrm{H}_{2}\right)$ (Rezaiyan and Cheremisinoff 2005, Song 2010). The water-gas shift (WGS) reaction widely utilized in industry can be used to augment the $\mathrm{H}_{2}$ content of syngas. In this process, steam reacts with $\mathrm{CO}$ to produce carbon dioxide and hydrogen $\left(\mathrm{CO}+\mathrm{H}_{2} \mathrm{O} \rightarrow \mathrm{CO}_{2}+\mathrm{H}_{2}\right)$.

Despite its deleterious effects on many living species, carbon monoxide is also the starting point for many food chains, especially in hydrothermal environments such as the deep sea, hot springs, and volcanoes. Carboxydothermus hydrogenoformans is one such organism that was isolated from a hot spring on Kunashir Island, Russia (Svetlichnyi et al. 1991). This extreme thermophilic bacillus uses $\mathrm{CO}$ as sole source of carbon and energy while catalyzing the WGS reaction.

Gasifiers, as all industrial machinery, may need to be stopped for maintenance or for emergency intervention.

\footnotetext{
* Correspondence: serge.guiot@cnrc-nrc.gc.ca

'Department of Microbiology, Infectiology and Immunology, Université de Montréal, Montreal H3C 3J7, Canada

${ }^{2}$ Bioengineering Laboratory, Energy, Mining and Environment, National

Research Council Canada, 6100 Royalmount Avenue, Montreal H4P 2R2, Canada
}

Full list of author information is available at the end of the article
Considering the high decay rate of $C$. hydrogenoformans (Zhao et al. 2013), it is mandatory to have a secondary carbon and energy source that would act as a back-up system in case CO fails to be delivered over an extended period of time to the biomass. That way, biomass concentration can be maintained, allowing a smooth restart of the WGS reaction with no lag time or the need to rebuild the bacterial population. In this regard, pyruvate could prove to be an interesting substitution substrate since $C$. hydrogenoformans was reported to be able to grow on it as an alternative carbon and electron source to carbon monoxide (Svetlichnyi et al. 1994). Pyruvate fermentation in anaerobic fermentative organisms leads to the production of acetyl-CoA and hydrogen (Hallenbeck and Benemann 2002). This reaction is catalyzed by two enzymes (Thauer et al. 1972, Carere et al. 2008): the pyruvate:ferredoxin oxidoreductase (POR), which catalyzes: pyruvate $+\mathrm{CoA}+2 \mathrm{Fd}_{\text {ox }} \rightarrow$ acetyl-CoA $+\mathrm{CO}_{2}+\mathrm{Fd}_{\text {red }}+2 \mathrm{H}^{+}$; and the pyruvate: formate lyase $(\mathrm{PFL})$, which catalyzes: pyruvate $+\mathrm{CoA} \rightarrow$ acetyl-CoA + formate.

As the reported growth information of C. hydrogenoformans on pyruvate was only qualitative, the objective of this study was to quantitatively assess its growth and activity kinetics on pyruvate and elucidate a potential impact of substrate alternation on both activities and products formation. 


\section{Materials and methods Culture medium}

C. hydrogenoformans (DSM 6008) was obtained from the German Collection of Microorganisms and Cell Cultures (DSMZ, Braunschweig, Germany). The strain was cultivated in shake-culture at $100 \mathrm{rpm}$ under strictly anaerobic conditions at $70^{\circ} \mathrm{C}$ in a basal mineral medium buffered with a bicarbonate-phosphate buffer. The medium as formulated by Zhao et al. (2011) contained (in $\mathrm{g} \cdot \mathrm{L}^{-1}$ of demineralized water): $\mathrm{KCl} 0.33, \mathrm{MgCl}_{2} \cdot 6 \mathrm{H}_{2} \mathrm{O} \quad 0.102$, $\mathrm{CaCl}_{2} \cdot 2 \mathrm{H}_{2} \mathrm{O}$ 0.015, $\mathrm{NH}_{4} \mathrm{Cl} 0.33, \mathrm{KH}_{2} \mathrm{PO}_{4} 0.136, \mathrm{NaHCO}_{3}$ 0.42 , yeast extract $0.05, \mathrm{Na}_{2} \mathrm{~S} \cdot 9 \mathrm{H}_{2} \mathrm{O}$ 0.7. The medium was supplemented with $10 \mathrm{~mL} \cdot \mathrm{L}^{-1}$ trace metals solution and $10 \mathrm{ml} \cdot \mathrm{L}^{-1}$ of vitamins solution prepared as described previously (Stams et al. 1993). All stock solutions were autoclaved, except for the vitamin solution, which was sterilized by filtration through $0.22 \mu \mathrm{m}$ filter membranes. The initial $\mathrm{pH}$ was adjusted between 6.8 and 7.0.

\section{Growth quantification}

The pyruvate activity tests were conducted in $120 \mathrm{~mL}$ serum bottles in quintuplicate. Bottles were filled with $30 \mathrm{~mL}$ of the growth medium, inoculated with $2 \mathrm{~mL}$ of C. hydrogenoformans at an initial concentration of 6.65 mg volatile suspended solid $(\mathrm{VSS}) \cdot \mathrm{L}^{-1}$, capped, and flushed with a gas mixture of $\mathrm{N}_{2} / \mathrm{CO}_{2}$ to establish anaerobic conditions. Starter cultures were active $C$. hydrogenoformans cultures that were cultivated on $\mathrm{CO}$ as sole source of carbon and energy. Headspace monitoring of these cultures was done prior to inoculation to ensure that they were not in latency phase. Bottles were then flushed with a high purity CO gas (100\%) and set to atmospheric pressure or spiked with a pyruvate solution to an initial concentration of $3.0 \pm 0.1 \mathrm{~g} \cdot \mathrm{L}^{-1}$, and incubated in the absence of light at $70^{\circ} \mathrm{C}$ and $100 \mathrm{rpm}$ in a rotary shaker (New Brunswick, Edison, NJ).

Microbial quantification in the bottles was performed immediately after substrate feeding (time 0), then intermittently until the end of experiment. Biomass quantification was achieved using chemical oxygen demand (COD) measurements which were then converted to VSS using a factor of $1.37 \mathrm{~g}$ COD $\cdot \mathrm{g}^{-1} \mathrm{VSS}$ based on the elemental formula of microbial biomass as $\mathrm{CH}_{1.79} \mathrm{O}_{0.5} \mathrm{~N}_{0.2} \mathrm{~S}_{0.005}$ (Roels 1983).

Both substrate (CO, pyruvate) depletion and catabolite $\left(\mathrm{H}_{2}, \mathrm{CO}_{2}\right.$, volatile fatty acids (VFA) and alcohols) production were monitored. The specific substrate uptake or product formation rates, expressed as $\mathrm{mol} \cdot \mathrm{g}^{-1} \mathrm{VSS} \cdot \mathrm{d}^{-1}$, were obtained by the rate of depletion or accumulation $\left(\mathrm{mol} \cdot \mathrm{d}^{-1}\right)$ per bottle divided by the number of grams of biomass-VSS as estimated in the bottle. The hydrogen yield $\left(\mathrm{Y}_{\mathrm{H} 2}\right)$ was expressed as a percentage of the $\mathrm{H}_{2}$ gas produced per $\mathrm{CO}$ consumed ( $\mathrm{mol} / \mathrm{mol})$.

\section{Analytical methods}

The COD was determined according to Standard Methods (Eaton et al. 2005), using a spectrophotometer DRB 200 (Hach Company, Loveland, CO).

Gas samples were obtained by withdrawing $300 \mu \mathrm{L}$ of gas from the bottle headspace using a gas-tight syringe (model 1750 Hamilton, Reno, NV). Gas composition $\left(\mathrm{H}_{2}, \mathrm{CO}, \mathrm{CO}_{2}\right)$ was measured by injecting this gas into a HP 6890 gas chromatograph (Hewlett Packard, Palo Alto, CA) equipped with a thermal conductivity detector (TCD) and a $11 \mathrm{~m} \times 3.2 \mathrm{~mm}$ 60/80 mesh Chromosorb 102 packed column (Supelco, Bellafonte, PA). The column temperature was held at $60^{\circ} \mathrm{C}$ for $7 \mathrm{~min}$ and increased to $225^{\circ} \mathrm{C}$ at a rate of $60^{\circ} \mathrm{C}$ per min. Argon was used as the carrier gas. The injector and detector were maintained at $125^{\circ} \mathrm{C}$ and $150^{\circ} \mathrm{C}$ respectively.

VFAs (i.e. acetic, propionic and butyric acids) were measured on an Agilent 6890 (Wilmington, DE) gas chromatograph (GC) equipped with a flame ionization detector (FID). $0.2 \mu \mathrm{L}$ samples were diluted 1:1 (vol./vol.) with an internal standard of iso-butyric acid in $6 \%$ formic acid, directly injected on a glass column of $1 \mathrm{~m} \times 2 \mathrm{~mm}$ Carbopack C (60-80 mesh) coated with 0.3\% Carbowax $20 \mathrm{M}$ and $0.1 \% \mathrm{H}_{3} \mathrm{PO}_{4}$. The column was held at $130^{\circ} \mathrm{C}$ for $4 \mathrm{~min}$. Helium was the carrier gas, fed at a rate of $20 \mathrm{~mL} \cdot \mathrm{min}^{-1}$. Both injector and detector were maintained at $200^{\circ} \mathrm{C}$.

For measurement of solvents (methanol, ethanol, acetone, 2-propanol, tert-butanol, n-propanol, sec-butanol, n-butanol) $100 \mu \mathrm{L}$ of liquid was transferred into a vial that had $20 \mathrm{~mL}$ of headspace and was crimp sealed with a Teflon-coated septum. The vial was heated at $80^{\circ} \mathrm{C}$ for $2 \mathrm{~min}$, then $1000 \mu \mathrm{L}$ of headspace gas was injected onto a DB-ACL2 capillary column of $30 \mathrm{~m} \times 530 \mathrm{~mm} \times 2 \mu \mathrm{m}$ using a Combipal autosampler (CTC Analytics AG, Zwingen, Switzerland). The column was held at $40^{\circ} \mathrm{C}$ for $10 \mathrm{~min}$. Helium was the carrier gas at a head pressure of 5 psi. The injector and the detector were maintained at $200^{\circ} \mathrm{C}$ and $250^{\circ} \mathrm{C}$, respectively.

Pyruvate was monitored using a high performance liquid chromatograph (HPLC) (Waters, Milford, MA) equipped with a model 600 pump, a model 717 Plus autosampler and a refractive index detector (model 2414) linked to a photodiode array (PDA) detector (model 2996). The separation was made on a $300 \mathrm{~mm} \times 7.8 \mathrm{~mm}$ ICSep IC ION-300 column (Transgenomic, Omaha, NE). The mobile phase was $0.01 \mathrm{~N} \mathrm{H}_{2} \mathrm{SO}_{4}$ at $0.4 \mathrm{~mL} \cdot \mathrm{min}^{-1}$. Analyses were carried out at $35^{\circ} \mathrm{C}$.

\section{Results}

C. hydrogenoformans was reported to grow on pyruvate as an alternative carbon and electron source to carbon monoxide (Svetlichnyi et al. 1994). C. hydrogenoformans activity and formed products were first quantified on 
pyruvate $\left(3.0 \pm 0.1 \mathrm{~g} \cdot \mathrm{L}^{-1}\right)$ with an initial microbial concentration of $6.65 \mathrm{mg} \mathrm{VSS} \cdot \mathrm{L}^{-1}$ for a feed-to-microorganisms ratio $(\mathrm{F} / \mathrm{M})$ of 515 . (Figure 1, Phase I). Over phase I, the highest pyruvate consumption activity (initial rate reported on initial biomass concentration) and the lowest activity (final rate reported on final biomass concentration) were $0.48 \pm 0.27$ and $0.21 \pm 0.03$ $\mathrm{mol} \cdot \mathrm{g} \mathrm{VSS}^{-1} \cdot \mathrm{d}^{-1}$, respectively. The corresponding product yields were $77,7,13$ and $75 \%$ ( $\mathrm{mol} / \mathrm{mol}$ pyruvate) for acetate, ethanol, hydrogen and $\mathrm{CO}_{2}$, respectively. The formation of trace methanol and 2-propanol were also observed. Once pyruvate was depleted, the cultures were flushed with CO $(90 \mathrm{~mL}$ headspace filled with $100 \%$ CO, 1 bar) only (phase II, Figure 1), then with CO and pyruvate simultaneously (phase III, Figure 1), at the same concentrations used in phases I and II. Substrate consumption ( $\mathrm{CO}$ and pyruvate) and products formation $\left(\mathrm{H}_{2}, \mathrm{CO}_{2}\right.$, acetate, ethanol) were continuously monitored. The results showed that substrate alternation had neither an impact over products yield nor on $\mathrm{CO}$ or pyruvate consumption rates. The 17 hours lag time in pyruvate consumption at the beginning of phase III was expected due to the simultaneous addition of $\mathrm{CO}$ and pyruvate at the end of phase II. Pyruvate consumption did not begin before $90 \%$ of the CO was consumed, indicating clear sequential substrate consumption. A significant discrepancy of $0.72 \mathrm{mmol}$ between $\mathrm{CO}_{2}$ and $\mathrm{H}_{2}$ content occurred when $C$. hydrogenoformans was grown on pyruvate in both phases I and III, clearly indicating that part of the $\mathrm{H}_{2}$ produced was also consumed. This difference could not be explained by the production of ethanol alone $(0.16 \mathrm{mmol})$. Interestingly, hydrogen consumption stopped once ethanol concentration in the medium reached $5.33 \mathrm{mmol} \cdot \mathrm{L}^{-1}$ (phase III).
Concurrently, an independent fresh growth experimental set was conducted on pyruvate alone to accurately assess the C. hydrogenoformans growth rate and yield on pyruvate, verify the reproducibility of the above results (Figure 2) and confirm the absence of lag time for growth and substrate consumption when $\mathrm{CO}$ is not present. The initial pyruvate concentration was $3.0 \pm 0.1 \mathrm{~g} \cdot \mathrm{L}^{-1}$, with an initial microbial concentration of $71.9 \mathrm{mg} \mathrm{VSS} \cdot \mathrm{L}^{-1}$ for $F / M$ of 43. Pyruvate consumption started within the first 4 hours compared to over 22 hours when in simultaneous presence of $\mathrm{CO}$ and pyruvate (Figure 1, Phase III). The observed growth rate was $0.03 \pm 0.005 \mathrm{~h}^{-1}$. Pyruvate consumption activity was stable throughout the experiment with the highest and lowest activity of 0.24 and $0.21 \mathrm{~mol} \cdot \mathrm{g} \mathrm{VSS}^{-1} \cdot \mathrm{d}^{-1}$, respectively. This corresponded to apparent growth yields of $3.51 \pm 0.69 \mathrm{~g} \mathrm{VSS} \cdot \mathrm{mol}^{-1}$ pyruvate (i.e. $4.28 \pm 0.54 \%$ by weight), respectively. The product yields were 72,24 and $3 \%$ ( $\mathrm{mol} / \mathrm{mol}$ pyruvate) for acetate, hydrogen and ethanol, respectively.

\section{Discussion}

Since pyruvate consumption by $C$. hydrogenoformans has not been thoroughly described in literature (Svetlichnyi et al. 1994), the present work allows a better understanding of this metabolism. When switching from $\mathrm{CO}$ to pyruvate, little lag time was observed versus the $17 \mathrm{~h}$ lag observed for the inverse (pyruvate to $\mathrm{CO}$ ). This could be explained by the number of steps involved in pyruvate degradation (Knappe and Sawers 1990, Bock and Schonheit 1995) as compared to CO. Indeed, C. hydrogenoformans is able to convert pyruvate to acetyl-CoA in a single step, using its pyruvate-ferredoxin oxidoreductase (POR) (Perumal et al. 2012). On the other hand, CO transformation to acetyl-coA requires 4 steps and three

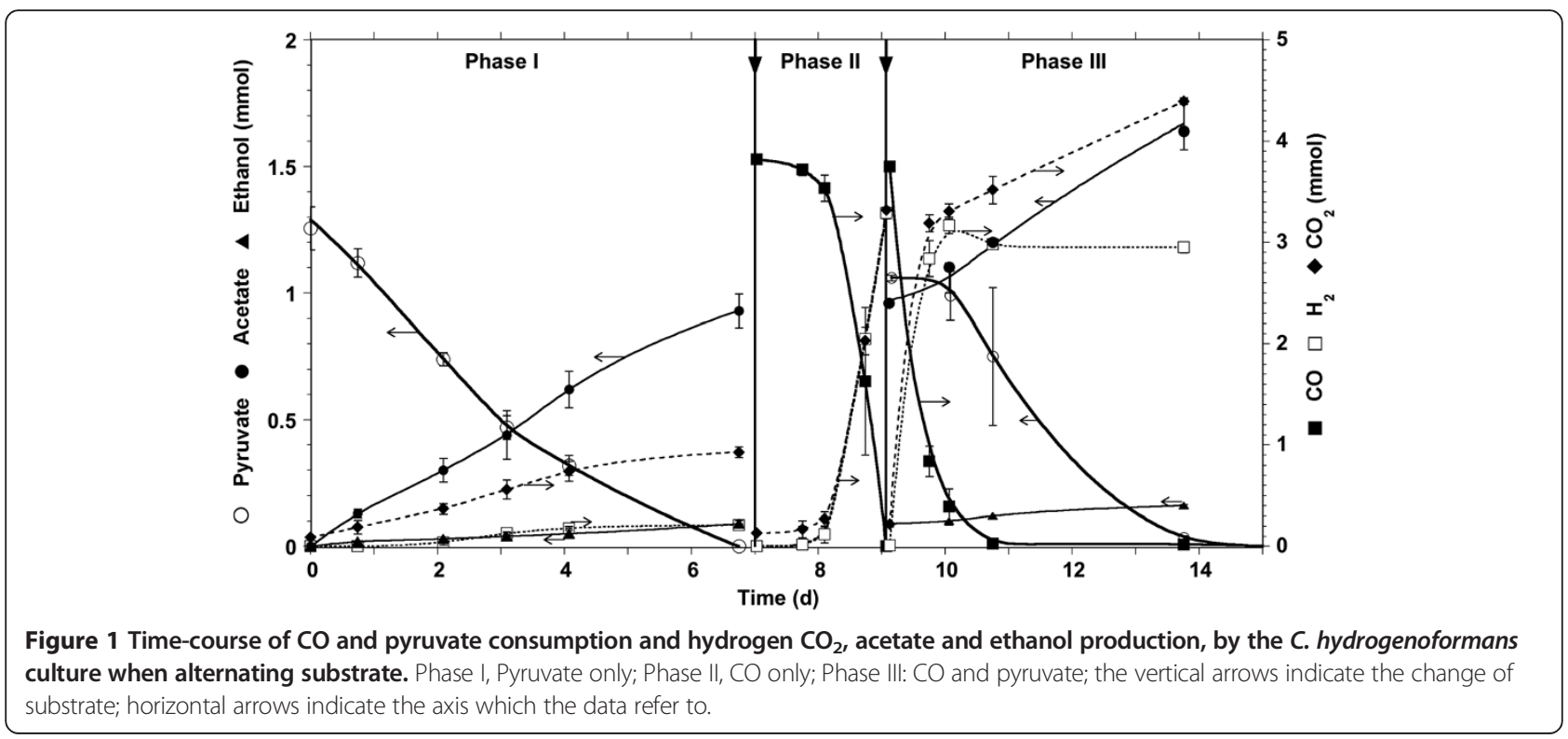




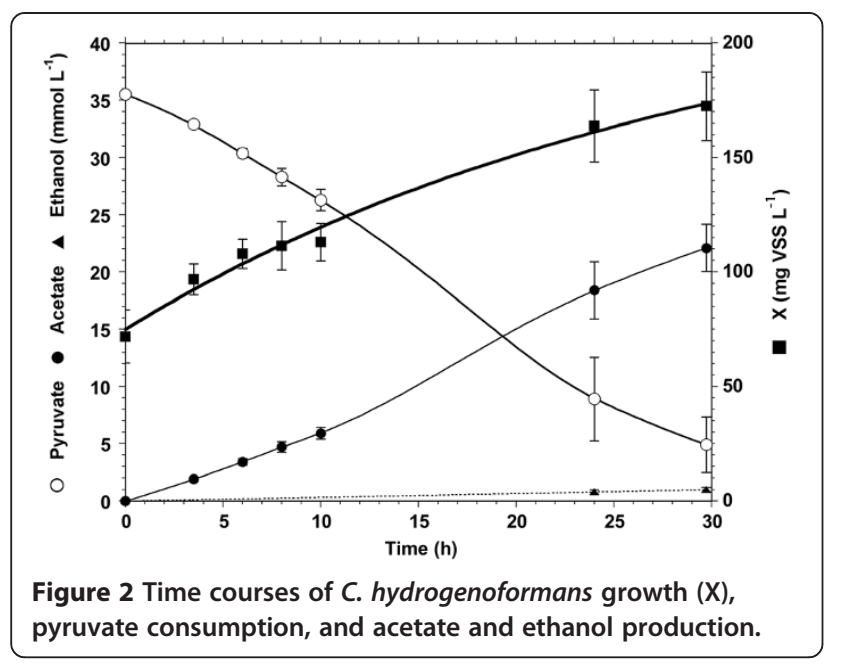

enzymes (Lu et al. 1990): the bifunctional CODH/ACS complex, the monofunctional $\mathrm{CODH}$, and a methylated corrinoid iron-sulfur protein (Ragsdale 2008). Also, the CO-related genes (coo operon) were found to be induced upon $\mathrm{CO}$ binding on the sensor and the transcriptional regulatory CooA protein (He et al. 1996, Aono et al. 2000, Wu et al. 2005). When assessing the activity profiles of the enzymes involved in pyruvate catabolism in Clostridium thermocellum (Rydzak et al. 2009), it was found that the expression level of the POR enzyme remained constant as growth progressed from early exponential to stationary phase. Hence, it was concluded that the changes of enzyme expression involved in pyruvate catabolism were negligible in response to growth (Rydzak et al. 2009). Assuming that the expression pattern of the POR superfamily is similar across Clostridia, these findings suggest that the POR enzyme is constantly expressed under anaerobic conditions as opposed to the CO-induced CODH (Sawers and Böck 1989, Knappe and Sawers 1990).

When C. hydrogenoformans was simultaneously fed with pyruvate and $\mathrm{CO}$, the substrates were sequentially consumed, the pyruvate being consumed only when $\mathrm{CO}$ is depleted. This has the appearance of a diauxie phenomenon, also named carbon catabolite repression (CCR) (Gorke and Stulke 2008), and defined as a regulatory phenomenon during which, in the presence of two carbon sources, gene expression and protein activity of the secondary carbon source are reduced. However in this case, the thermodynamics suggested that pyruvate should have been consumed before CO. The Gibbs free energy changes at $70^{\circ} \mathrm{C}$ and neutral $\mathrm{pH}$ were as follows: $\Delta \mathrm{G}^{\prime}=-45 \mathrm{~kJ} / \mathrm{mol}$ for the the reaction $\mathrm{CO}+\mathrm{H}_{2} \mathrm{O} \rightarrow$ $\mathrm{CO}_{2}+\mathrm{H}_{2}$, with $\mathrm{p}_{\mathrm{CO}}$ at $1.1 \mathrm{~atm}, \mathrm{p}_{\mathrm{CO} 2}$ at 0.06 atm and $\mathrm{p}_{\mathrm{H} 2}$ at $0.01 \mathrm{~atm} ; \Delta \mathrm{G}^{\prime}=-81 \mathrm{~kJ} / \mathrm{mol}$, for the reaction $\mathrm{CH}_{3} \mathrm{COCOO}^{-}+2 \mathrm{H}_{2} \mathrm{O} \rightarrow \mathrm{CH}_{3} \mathrm{COO}^{-}+\mathrm{HCO}_{3}^{-}+\mathrm{H}^{+}+\mathrm{H}_{2}$, with $\mathrm{p}_{\mathrm{H} 2} 0.01 \mathrm{~atm},\left[\mathrm{CH}_{3} \mathrm{COCOO}^{-}\right] 0.04 \mathrm{M},\left[\mathrm{CH}_{3} \mathrm{COO}^{-}\right]$ $0.03 \mathrm{M},\left[\mathrm{HCO}_{3}{ }^{-}\right] 0.005 \mathrm{M}$. This thermodynamic prediction is consistent with the observed growth kinetics, with a faster rate for pyruvate $\left(\mu 0.03 \mathrm{~h}^{-1}\right)$ than on $\mathrm{CO}\left(\mu 0.01 \mathrm{~h}^{-1}\right)$ (Zhao et al. 2013). Thus diauxie, sensu stricto, cannot be retained as an explanation. The substrate consumption sequence as observed, is probably due to $\mathrm{CO}$ toxicity to the pyruvate pathway present in C. hydrogenoformans (Uniprot accession numbers: Q3ADQ7; Q3AFU1; Q3AFU0; Q3ACZ5). CO has proven to be a potent inhibitor to pyruvate oxidation in another strictly anaerobic hyperthermophile, Pyrococcus furiosus (Blamey and Adams 1993) and inhibited the hydrogenase activity of the POR in Clostridium thermoaceticum (Menon and Ragsdale 1996).

The observed discrepancy between $\mathrm{H}_{2}$ and $\mathrm{CO}_{2}$ content during pyruvate fermentation (Figure 1) with no subsequent by-product formation besides acetate strongly suggests a homoacetogenic activity of the bacterial strain. All the genes in the acetyl-CoA pathway have been identified in the C. hydrogenoformans genome (Wu et al. 2005) making $\mathrm{CO}_{2}$ reduction to acetate possible $\left(2 \mathrm{CO}_{2}+4\right.$ $\left.\mathrm{H}_{2} \rightarrow \mathrm{CH}_{3} \mathrm{COO}^{-}+\mathrm{H}^{+}+2 \mathrm{H}_{2} \mathrm{O}\right)$. The stoichiometry-based combination of this homoacetogenic reaction with the pyruvate-to-acetate and pyruvate-to-ethanol reactions predicts a $\mathrm{CO}_{2}$ net production which is nearly 4 times higher than that of hydrogen, when the yields observed for acetate, ethanol and hydrogen are used as actual stoichiometric coefficients of the balanced chemical equation: this is quite in line with the phase I observations. Adding to this, acetogenic shift of $C$. hydrogenoformans from CO was showed in final stages of incubation (Henstra and Stams 2011). Hence, homoacetogenesis would explain the linear increase in acetate in phase III (Figure 1) prior to pyruvate consumption.

In phase III (Figure 1), although hydrogen (issued from the WGS reaction) and pyruvate were present in large amounts, and that ethanol production from pyruvate and hydrogen $\left(\Delta G^{\circ}=-57 \mathrm{~kJ} /\right.$ reaction $)$ is more thermodynamically favourable than acetate production from pyruvate $\left(\Delta G^{\circ}=-47 \mathrm{~kJ} /\right.$ reaction $)$, hydrogen was not significantly consumed while ethanol did not reach a concentration higher than $5.3 \mathrm{mM}$. This could be explained by the fact that the alcohol dehydrogenase present in $C$. hydrogenoformans (NCBI Accession AF244667) is inhibited by ethanol as it was demonstrated in another thermophilic clostridium, C. thermocellum, at an even lower ethanol concentration $(0.14 \mathrm{mM})$ (Lamed and Zeikus 1980, Lovitt et al. 1988).

To conclude, the present work revealed new growthrelated features of $C$. hydrogenoformans. Growth of the bacterium on pyruvate as sole $\mathrm{C}$ source was fully characterized. When grown simultaneously on pyruvate and $\mathrm{CO}$, pyruvate consumption was initiated upon $\mathrm{CO}$ depletion. This was attributed to inhibition of pyruvate oxidation by $\mathrm{CO}$. While the bulk of acetate derived from 
pyruvate, it is likely that there was also some homoacetogenic activity, thus contributing to the formation of acetate from $\mathrm{H}_{2}$ and $\mathrm{CO}_{2}$, which had never previously been shown with C. hydrogenoformans.

\section{Competing interests}

The authors declare that they have no competing interests.

\section{Authors' contributions}

$\mathrm{RC}$ and $\mathrm{YZ}$ designed the experiment; $\mathrm{YZ}$ and $\mathrm{MH}$ carried out the experimental work; RC, MH and SRG interpreted the results; $\mathrm{MH}$ and SRG wrote the manuscript. All authors read and approved the final manuscript.

\section{Acknowledgment}

The authors wish to thank P. Mehta, M.-J. Lévesque, L. Paquet, C. Beaulieu, A. Corriveau and S. Deschamps for their assistance and discussions. One of the authors (Y.Z.) was supported by the Canada NRC-China MOE Research and Post-doctoral Fellowship Program, and another (M.H.), by the Natural Sciences and Engineering Research Council of Canada (grant 185778-2009). NRC paper No. 53123.

\section{Author details}

1Department of Microbiology, Infectiology and Immunology, Université de Montréal, Montreal H3C 3J7, Canada. Bioengineering Laboratory, Energy, Mining and Environment, National Research Council Canada, 6100 Royalmount Avenue, Montreal H4P 2R2, Canada. ${ }^{3}$ Institute of Biophysics, Chinese Academy of Sciences, Chaoyang District, Beijing 100101, P.R. China

Received: 11 June 2013 Accepted: 27 September 2013

Published: 7 October 2013

\section{References}

Aono S, Honma Y, Ohkubo K, Tawara T, Kamiya T, Nakajima H (2000) CO sensing and regulation of gene expression by the transcriptional activator CooA. J Inorg Biochem 82(1-4):51-56

Blamey JM, Adams MWW (1993) Purification and characterization of pyruvate ferredoxin oxidoreductase from the hyperthermophilic archaeon Pyrococcus furiosus. Biochim Biophys Acta 1161(1):19-27

Bock A-K, Schonheit P (1995) Growth of Methanosarcina barkeri (Fusaro) under nonmethanogenic conditions by the fermentation of pyruvate to acetate: ATP synthesis via the mechanism of substrate level phosphorylation. J Bacteriol 177(8):2002-2007

Carere C, Kalia V, Sparling R, Cicek N, Levin DB (2008) Pyruvate catabolism and hydrogen synthesis pathway genes of Clostridium thermocellum ATCC 27405. Indian J Microbiol 48(2):252-266

Eaton AD, Clesceri LS, Rice EW, Greenberg AE (2005) Standard methods for the examination of water and wastewater, 21st edn. American Public Health Association, American Water Works Association, Water Environment Federation, Washington, D.C

Gorke B, Stulke J (2008) Carbon catabolite repression in bacteria: many ways to make the most out of nutrients. Nat Rev Microbiol 6(8):613-624

Hallenbeck PC, Benemann JR (2002) Biological hydrogen production: fundamentals and limiting processes. Int J Hydrogen Energy 27:1185-1193

He Y, Shelver D, Kerby RL, Roberts GP (1996) Characterization of a CO-responsive Transcriptional Activator from Rhodospirillum rubrum. J Biol Chem 271(1):120-123

Henstra AM, Stams AJM (2011) Deep conversion of carbon monoxide to hydrogen and formation of acetate by the anaerobic thermophile Carboxydothermus hydrogenoformans. Int J Microbiology(641582):1-4, http://dx.doi.org/10.1155/2011/641582

Knappe J, Sawers G (1990) A radical-chemical route to acetyl-CoA: the anaerobically induced pyruvate formate-lyase system of Escherichia coli. FEMS Microbiol Let 75(4):383-398

Lamed R, Zeikus JG (1980) Ethanol production by thermophilic bacteria: relationship between fermentation product yields of and catabolic enzyme activities in Clostridium thermocellum and Thermoanaerobium brockii. J Bacteriol 144(2):569-578

Lovitt RW, Shen GJ, Zeikus JG (1988) Ethanol production by thermophilic bacteria: biochemical basis for ethanol and hydrogen tolerance in Clostridium thermohydrosulfuricum. J Bacteriol 170(6):2809-2815
Lu WP, Harder SR, Ragsdale SW (1990) Controlled potential enzymology of methyl transfer reactions involved in acetyl-CoA synthesis by CO dehydrogenase and the corrinoid/iron-sulfur protein from Clostridium thermoaceticum. J Biol Chem 265(6):3124-3133

Menon S, Ragsdale SW (1996) Unleashing hydrogenase activity in carbon monoxide dehydrogenase/acetyl-CoA synthase and pyruvate:ferredoxin oxidoreductase. Biochemistry 35(49):15814-15821

Perumal R, Selvaraj A, Ravichandran S, Kumar G (2012) Computational kinetic studies of pyruvate metabolism in Carboxydothermus hydrogenoformans Z2901 for improved hydrogen production. Biotech Bioprocess Eng 17(3):565-575

Ragsdale SW (2008) Enzymology of the Wood-Ljungdahl pathway of acetogenesis. Ann N Y Acad Sci 1125:129-136

Rezaiyan J, Cheremisinoff NP (2005) Gasification technologies: a primer for engineers and scientists. Taylor \& Francis, Portland, OR

Roels JA (1983) Energetics and kinetics in biotechnology. Elsevier Biomedical Press, Amsterdam

Rydzak T, Levin DB, Cicek N, Sparling R (2009) Growth phase-dependant enzyme profile of pyruvate catabolism and end-product formation in Clostridium thermocellum ATCC 27405. J Biotech 140(3-4):169-175

Sawers G, Böck A (1989) Novel transcriptional control of the pyruvate formatelyase gene: upstream regulatory sequences and multiple promoters regulate anaerobic expression. J Bacteriol 171(5):2485-2498

Song C (2010) Introduction to hydrogen and syngas production and purification technologies. In: Liu K, Song C, Subramani V (eds) Hydrogen and syngas production and purification technologies. J. Wiley \& Sons, Hobocken, NJ, pp 1-13

Stams AJM, Van Dijk JB, Dijkema C, Plugge CM (1993) Growth of syntrophic propionate-oxydizing bacteria with fumarate in the absence of methanogenic bacteria. Appl Environ Microbiol 59(4):1114-1119

Svetlichnyi VA, Sokolova TG, Gerhardt M, Ringpfeil M, Kostrikina NA, Zavarzin GA (1991) Carboxydothermus hydrogenoformans gen. nov., sp. nov., a CO-utilizing thermophilic anaerobic bacterium from hydrothermal environments of Kunashir Island. Syst Appl Microbiol 14(3):254-260

Svetlichnyi VA, Sokolova TG, Kostrikina NA, Lysenko AM (1994) A new thermophilic anaerobic carboxydotrophic bacterium Carboxydothermus restrictus sp. nov. Microbiology 63(3):294-297

Thauer RK, Kirchniawy FH, Jungermann KA (1972) Properties and function of the pyruvate-formate-lyase reaction in clostridiae. Eur J Biochem 27(2):282-290

Wu M, Ren Q, Durkin AS, Daugherty SC, Brinkac LM, Dodson RJ, Madupu R, Sullivan SA, Kolonay JF, Nelson WC, Tallon LJ, Jones KM, Ulrich LE, Gonzalez JM, Zhulin IB, Robb FT, Eise JA (2005) Life in hot carbon monoxide: The complete genome sequence of Carboxydothermus hydrogenoformans Z-2901. PLoS Genet 1(5):e65

Zhao Y, Cimpoia R, Liu Z, Guiot SR (2011) Orthogonal optimization of Carboxydothermus hydrogenoformans culture medium for hydrogen production from carbon monoxide by biological water gas shift reaction. Int J Hydrogen Energy 36(17):10655-10665

Zhao Y, Haddad M, Cimpoia R, Liu Z, Guiot SR (2013) Performance of a Carboxydothermus hydrogenoformans-immobilizing membrane reactor for syngas upgrading into hydrogen. Int J Hydrogen Energy 38(5):2167-2175

doi:10.1186/2191-0855-3-60

Cite this article as: Haddad et al:: Growth profile of Carboxydothermus hydrogenoformans on pyruvate. AMB Express 2013 3:60.

\section{Submit your manuscript to a SpringerOpen ${ }^{\odot}$ journal and benefit from:}

- Convenient online submission

- Rigorous peer review

- Immediate publication on acceptance

- Open access: articles freely available online

- High visibility within the field

- Retaining the copyright to your article

Submit your next manuscript at $>$ springeropen.com 